\title{
Is Social Entrepreneurship Better for Workers? The Influence of Work Experience in Croatian Social Cooperatives on Perceived Well-Being ${ }^{1}$
}

Jelena PUĐAK (iD) orcid.org/0000-0002-0549-5802

Institute of Social Sciences Ivo Pilar, Zagreb, Croatia jelena.pudjak@pilar.hr

\section{Dražen ŠIMLEŠA}

Institute of Social Sciences Ivo Pilar, Zagreb, Croatia drazen.simlesa@pilar.hr

\section{ABSTRACT}

This paper aims to examine the motivations, values, and job satisfaction among the people employed in the sector of social entrepreneurship that were obtained through a qualitative study of ten Croatian social cooperatives. In our analysis, we interpreted the experiences of working in a social enterprise from the employee perspective. Our findings suggest that the participants/employees of social enterprises favour intrinsic motivation and values related to their jobs, that they describe their working conditions in social enterprises positively, and that they share a perceived increase in the quality of life since having started working at a social enterprise. The described relations between motivation, job experiences, and participatory management allowed us to build upon and extend the existing body of research on motivation and job satisfaction in the social economy sector.

Key words: social entrepreneurship, intrinsic motivation, values, job satisfaction

\section{INTRODUCTION}

Social entrepreneurship and economy have become increasingly prominent and accepted globally as economic and business models that aim at fulfilling a social or societal mission rather than pursuing uncontrolled growth and amassing profit (Perić and Alpeza, 2011; OECD, 2013). An upward trend in this development has

This paper is based on the data collected for the project iPRESENT, the Installation Project of the Croatian Science Foundation for Research about Social Entrepreneurship (\# 5332). 
been observed in particular since the last economic crisis that started in 2008 when the need to create a more equitable and responsible economic model and business behaviour became more apparent. At this point, even the mainstream social circles have started to question the relationship between economic wealth and the quality of life of the majority, as well as the attitude towards resources and the ecosystem (Jackson, 2009; Stiglitz, Sen and Fitoussi, 2009). The social economy sector is referred to as "no longer a peripheral phenomenon but a genuine institutional pillar of economy" (Bouchard, 2010: 11), "a pole of social utility between the capitalist sector and the public sector" in European society (Chaves Avila and Monzón Campos, 2010:117-118), which "plays a crucial role in the European economic landscape and should be acknowledged, accepted, and supported as such" (European Parliament, 2009).

In the European context, social entrepreneurship is a broad concept covering a plethora of economic models and a wide range of organisations. What many of them have in common, apart from creating a social impact and reinvesting income into projects of public relevance, is participatory democratic management that places the employee at the centre, thereby changing the economy for both the consumers and its co-creators. Therefore, the experience of working at a social enterprise, motivations, and values shared by the employees are the focus of our research. Shifting the focus to workers' evaluations enabled us to detect the impact of social entrepreneurship on workers' perceived well-being. This also allowed us to identify whether social entrepreneurship fulfilled one of its social missions regarding participatory management of an enterprise.

The paper begins with an overview of the fundamental theoretical concepts of the social economy, with particular focus on its position in the Croatian context. This is followed by an overview of recent quantitative and qualitative research on the impact of work on the segments of social and private lives of people employed in social enterprises, as well as some theoretical and empirical perspectives on the types of employees' motivation. The majority of the paper is dedicated to presenting the results of our research and the discussion. We focused in particular on the examination of social enterprise employees' motivations and job satisfaction, as well as on the impact of job experience on their sense of well-being. In the conclusion of our paper, we identify the specific scientific contribution of our findings. Specifically, we provide a descriptive analysis of the multiple aspects of job experience and motivation in the nascent stage of the social entrepreneurship sector, we examine how these aspects interact, and we analyse whether these experiences correspond to the theoretical conceptualisations of the sector. 


\section{THEORETICAL CONCEPTUALISATION OF SOCIAL ENTREPRENEURSHIP AND THE CROATIAN CONTEXT}

It is commonly believed that a social entrepreneur or a social enterprise refers to a business idea or initiative that manages to meet its social mission in an economically sustainable manner (Fitzhugh and Stevenson, 2015). In Europe, attention has been paid to economic and social dimensions and dimensions of participatory governance, particularly in the scope of EMES - the European research network that centres around social enterprises, economy, and related terms. There are three sets of criteria social enterprises have to meet (Defourny and Nyssens, 2012):

1. Economic/entrepreneurial: a) a continuous activity producing goods and services; b) a significant level of economic risk; c) a minimum amount of paid work.

2. Social: a) an explicit aim to benefit the community; b) an initiative launched by a group of citizens or civil society organisations; c) a limited profit distribution.

3. Participatory governance: a) a high degree of autonomy; b) a decision-making power not based on capital ownership; c) a participatory nature of the organisation.

The European approach follows the standard notion of social entrepreneurship in the USA in terms of emphasising the importance of economic and entrepreneurial spirit or an idea that aims to fulfil a social or societal mission. The two approaches are different in that the European approach significantly emphasises the way a process or an organisation is managed, that is, it explores the relationship between ownership and managing a social enterprise idea (European Commission, 2013).

Croatia initially adopted social entrepreneurship through the Anglo-Saxon approach (Comolli, Varga and Varga, 2007; Rosandić and Varga, 2012), which mostly focused on empowering civil society organisations to boost their income, that is, to increase profit from self-financing activities in line with the American "earned income" approach (Defourny and Nyssens, 2012). However, during the pre-accession to the EU, Croatia adopted the European approach to the concept. In the key document titled Strategy of Development of Social Entrepreneurship in the Republic of Croatia 2015-2020 social entrepreneurship is defined in the following manner (MRMS, 2015: 7): "Enterprise based on the principles of social, environmental, and economic sustainability, wherein the entire or the majority of accrued profit/excess income is invested for the well-being of the community." 
However, the sector is still underdeveloped in Croatia. Out of four Strategy objectives, only one is being pursued - the public funding of the sector, which, as part of the EU practice, is implemented by tenders to the Ministry of Labour and Pension System (Šimleša, Puđak and Bušljeta Tonković, 2019; Monzón Campos and Chaves Avila, 2016). Apart from poor institutional background, the lack of both human resources and entrepreneurial skills, social entrepreneurship in Croatia is considered mostly in the context of strengthening the labour market for the hard-toemploy, which is a trait shared by countries where the sector is developed poorly (Bežovan, Matančević and Baturina, 2016; Šimleša et al., 2019).

In our paper, we will use the term "social entrepreneurship" since it became widely used in the Croatian context and functions as the basic concept of the Strategy. However, the term describes what the European context defines as a social enterprise or, more broadly, social economy. It is important to emphasise this in order to avoid terminological ambiguity and misinterpretations of the key concepts we are focusing on. "Social economy" is a prominent European meta-term that encompasses foundations, civil society organisations, cooperatives, and mutual organisations, which aim to meet their social missions using collective resources. The integral part of the social economy is a social enterprise. Social enterprise is the most recent concept that is currently on the rise and finding its place in the sector terminology (Monzón Campos and Chaves Avila, 2016). As already mentioned, apart from fulfilling a social mission, a social enterprise insists on an entrepreneurial initiation/action, gaining profit from market activities and, most importantly, developing participatory decision-making and (co)deciding on important matters among all stakeholders (Borzaga and Galera, 2014).

\section{OVERVIEW OF EXISTING RESEARCH}

It is vital to measure the satisfaction of people employed in social enterprises and users of their products and/or services. It is also important to capture their attitudes towards the activities of other stakeholders since it provides a genuine image of the organisation. This also keeps the organisation from dealing with mission drift, which is a frequently mentioned and analysed phenomenon that refers to deviating from the basic goal of fulfilling a social mission (Millstone, 2013; Pérotin, 2015; Utting, 2015). This occurs due to the sudden growth of an organisation or the prevalence of managerial and business principles over human and ethical values (Millstone, 2013; Pérotin, 2015; Utting, 2015).

We can single out a few studies conducted in Europe with a focus on motivation and non-material aspects of job satisfaction amongst employees of social enterprises. The presence of non-material aspects of job satisfaction has in particular 
been examined in Italy. These studies concluded that intrinsic motivation components such as a sense of belonging to a work organisation, shared values and the ability to achieve self-realisation have a positive impact on job satisfaction (Borzaga et al, 2014; Depedri, Tortia, and Carpita, 2010). Some findings also indicate that a stimulating work environment improves the well-being of each worker. This confirms the findings of previous research, which shows that quality decision-making is the most relevant aspect of perceived procedural fairness (Depedri et al., 2010). In the Trentino region, research conducted among various businesses indicates that employment in cooperative enterprises increases the social trust of workers by $47.5 \%$ relative to employment in public enterprises or $36.9 \%$ relative to employment in private enterprises (Sabatini, Modena and Tortia, 2012). Furthermore, organisations with a less hierarchical model of governance and organisations that do not aim to maximise profit play a crucial role in the diffusion of trust and accumulation of social capital (Sabatini et al., 2012).

The complexity of motivators in the behaviour of employees excludes the possibility of reducing motivation to a single dimension, such as non-monetary motivation. Research shows that employees value extrinsic motivations, such as job stability and salary (Borzaga et al., 2014; Becchetti, Castriota and Tortia, 2013). However, intrinsic components, such as shared values, a sense of belonging, the ability to achieve self-realisation and usefulness, are ranked very high on the Likert scale (Borzaga et al, 2014). Besides, despite extra hours (partially unpaid overtime), which can negatively affect wages, intrinsically motivated employees receive higher wages since intrinsic motivations create extra productivity, which compensates for the amount of job donated and leads to higher pay (Becchetti et al., 2013).

We will also mention two qualitative studies conducted in Great Britain on the impact of working at a social enterprise on the health and well-being of employees. Both studies showed a positive impact of working at a social enterprise on the health and well-being of employees through multiple aspects of intrinsic motivators and/or values (Chandler, 2016; Macaulay et al., 2017). The presence of intrinsic motivation among social entrepreneurship employees is described through the perceived social impact of their work, values they share with colleagues, enhanced social connectedness, employability, increased sense of autonomy and enhanced confidence (Chandler, 2016; Macaulay et al., 2017). However, some negative aspects of working at a social enterprise are found as well, such as concerns over job security; long working hours and poor work-life balance (Chandler, 2016).

Within the specifically Croatian context, there is no research closely connected to the topic of our paper. There are, nevertheless, two qualitative studies that help shape the context of our research: a case study of the decision-making processes in social enterprises in Croatia (Stubbs and Vidović, 2017), and a study of the third 
sector's impact on its human resources (Baturina, 2018). Considering the aspect of participatory governance, the former study concludes, among other things, that there is a complex dynamic between formal and informal types of governance, and that informal hierarchy is present in the decision-making process (Stubbs and Vidović, 2017). The latter study concludes that the motivation for working at a social enterprise is mostly altruistic, that human resources have a better chance of learning, and have developed flexibility through work (Baturina, 2018). ${ }^{2}$ Based on the description of the importance of social entrepreneurship in the European context (section 2), in our research, we focus on the last two areas, which cover the issues of democratic management and job satisfaction, including employees' motivations. Our research is therefore placed within the context of the existing body of research on non-material aspects of job satisfaction conducted in Europe. We, however, also extend previous research by further locating our study within the nascent stage of the sector's development, which has not been explored by previous studies. Since there has been relatively scarce research on social entrepreneurship in Croatia, and there has been none focusing on the satisfaction of employees of social enterprises, we have decided to approach the actors and capture their views on the important topics related to social entrepreneurship.

\section{RESEARCH DESIGN AND METHODOLOGY}

\subsection{Conceptualisation}

Since we were examining employees' motivation, we begin by presenting basic theoretical frameworks and empirical findings regarding different types of motivation that proved to be useful in our research. We can distinguish between two basic types of motivations: intrinsic and extrinsic. Intrinsic motivations are connected to non-material needs and are described as a driver of human behaviour that goes beyond the satisfaction of mere physiological and material security needs (Becchetti et al., 2013). More specifically, intrinsic motivation entails self-realisation, good interpersonal workplace relations, inclusion, and autonomy in decision-making. A job entails both intrinsic and extrinsic needs (material and/or other forms of separate compensation) to which individuals ascribe various intensities of importance (Depedri et al., 2010).

2 It is important to note that in this study there were considerable differences in sampling and the focus of the research question. Unlike in our research, the sample consisted of actors holding management positions and actors from the NGO sector. Besides, the study largely focused on volunteer work, which influenced the conclusion about the presence of altruistic motivations. 
However, Ryan and Deci (2000) bring the concept of need satisfaction into the discussion on motivation types, making the distinction gradual and flexible (see also Baard, Deci and Ryan, 2004). In that case, extrinsic motivation can include personal endorsement through fulfilling the intrinsic needs of competence, autonomy, and relatedness, which renders extrinsic motivation much more than mere compliance and brings it closer to the opposite pole of intrinsic motivations (Ryan and Deci, 2000). It is also important to mention that the interpersonal climate created in the workplace promotes self-motivation and satisfaction and leads to a higher level of trust and well-being (Baard et al., 2004).

\subsection{Methodology and Sampling}

Besides analysing quantitative economic indicators of the sector, it is logical to analyse the qualitative aspects of employee satisfaction considering the sector's focus on a social mission (Bell and Willmott, 2014). This becomes even more evident if we take into account the sector's goals of management transformation and relation to employees that were in the focus of our research.

In the sector of social entrepreneurship, these interpretations serve as communication tools of social economy actors before the public, donators, local community, and users.

We conducted a qualitative study ${ }^{3}$ among the most active organisations from the social enterprise database (Šimleša et al., 2015a). Out of 20 social cooperatives we opted for ten with the largest number of employees in order to recruit enough participants per group. Our selection was also guided by variability: we included organisations that were active in different parts of Croatia and those that encompassed various core businesses. We conducted group interviews with employees of these organisations in the period between April and July $2016 .{ }^{4}$ In these interviews, we aimed to elicit reflections and attitudes relating to four main areas: definition, motivation, values, and job satisfaction.

Our research was guided by the following research questions: 1) What type of values and motivation do employees working at social enterprises have? 2) Does employees' job experience at a social enterprise correspond to its goal and mission? 3) How does employees' work experience reflect on their perceived well-be-

The research was carried out as part of the scientific project funded by the Croatian Science Fund in the period 2014-2017.

4 The interviews were taped with the consent of the participants, and the audiotapes were then transcribed for analysis. Before the interview, the participants were notified of the purpose and aims of the research, stages of the research, and their rights as participants. The participants also signed an informed consent form to participate in the research. 
ing? In pursuing the answers to these questions, we used descriptive qualitative methodology. Qualitative analysis was selected in order to best achieve the purpose of the research, that is, to understand and describe social behaviour within the context of the social economy. The analysis allowed us to develop concepts on several abstract levels and thematic networks we used to interpret the results (Attride-Stirling, 2001; Charmaz, 2000).

The sample was purposive and consisted of social entrepreneurship actors listed in the social enterprise database, which encompasses 90 legal entities, out of which there are 20 social cooperatives. Ten group interviews were conducted with employees of ten cooperatives. Sixty-eight participants volunteered to take part in the interviews: from six to eight interviewees per group. The groups consisted of interviewees who were employees and, in some cases, stakeholders at the same time (which is common in cooperative organisations). The interviewees worked in different positions and jobs, depending on the type of organisation, ranging from service activities to small factory jobs and manufacturers. However, within a group, the interviewees worked mostly on the same jobs, except foremen who participated in interviews arranged in two groups. The groups were heterogeneous regarding gender and age. All social enterprises that entered the sample were small business organisations (up to 15 employees). This sample scope resulted in a satisfactory level of data density and saturation, that is, thematic repetition in the participants' answers. The interviews were then analysed using a computer program for qualitative data processing (Atlas.ti 7). The following procedures were used in the analysis of the transcribed material: simultaneous collection of material and analysis, multi-level open coding, and theme/category development. In this manner, we inductively developed fundamental concepts that enabled the research questions to be answered.

The interviews covered the following topics: personal definition of social entrepreneurship, fundamental values of social entrepreneurship, motivation, job satisfaction and overall experience of working at a social enterprise. By interviewing the participants on these topics, we were able to answer the research questions by describing the value orientations of cooperative employees regarding their work preferences and types of motivation. That enabled us to shed light on the impact of working at a social enterprise on the self-perceived well-being of employees.

Initially, we approached the potential interviewees via e-mail. We sent a request for participation to the official e-mail address of a given cooperative. A person in charge of human resources would forward that request and the information about the research to a targeted group (workers of the cooperative), who then volunteered to participate. Given the prompt and sufficient response, we consider that the theme and goals of the research were perceived positively, which might have 
had a positive influence on the perception of the researchers. However, the presence of a researcher contributed to the initial shyness of the interviewees in the context of a group interview. The interviewees, therefore, had to be individually encouraged to share their views. In that sense, some answers could have been more extensive or even different had those questions been asked later in the interview when the interviewees talked more freely.

We opted for group interviews in order to capture the joint job experience of workers in social cooperatives, as well as to see instances of consensus or disagreement amongst the workers on the topics we were interested in. This was important since social entrepreneurship places emphasis on joint decision-making and procedural fairness. Another reason for choosing group interviews was the relevance of contextual aspects of a job to workers' motivation, which was shown by previous studies. Nevertheless, we were not so much focused on the interaction among members of the group, and that interaction was not the subject of analysis per se ${ }^{5}$ (Brown and Edmunds, 2011). However, the group setting inevitably had some influence on the conversation flow, as well as on individual answers. The interviewees certainly inspired each other's answers, but this was not considered entirely a weakness of the research since the joint experience at a workplace was one of the reasons we opted for group interviews. At the beginning of each interview, the interviewees encouraged each other to participate and share opinions. As the interview progressed, the interviewees were speaking more freely and openly, so there was no need to additionally encourage individuals to participate. During sample planning, we kept an eye on maintaining group homogeneity with respect to the key characteristic for analysis (in our case that was job position). Having groups that were homogenous in that way was important to minimise refraining from providing answers, which could have been caused by fear or shame in the presence of superiors. It should be noted that group interviews will often reproduce the socially accepted, normative discourse within a group and that individuals that have unpopular views or less self-confidence are prone to refrain from answering (Smithson, 2007). However, despite the general consensus reached within each group, certain questions steered the discussion further away in some groups, which resulted in some interviewees expressing different opinions. This contributed to our confidence that the interviewees talked openly.

The transcribed material was first analysed by one of the authors of this paper. After finishing coding and the theme development, the initial results were discussed

Unlike group interviews, focus group analysis will place greater emphasis on the interaction within the group. Even though Hughes and Dumont (1993) define focus groups as in-depth group interviews, recently, when talking about focus groups, some authors have placed much more emphasis on group interaction as a unit of analysis (Smithson, 2007; Acocella, 2011). 
between both authors, and after a few adjustments, the final number of codes and themes was agreed on. The categories were developed jointly by both authors with the goal of designing an explanatory framework. Deviant cases appeared in three themes (and two categories) regarding quality of life, cooperation, and competition. The deviant cases were integrated into the analysis and have helped to explain the researched phenomenon by integrating the broader social context and narrower contexts (job positions) of workers, as it will be shown in the research results.

\section{RESEARCH RESULTS - QUALITATIVE ANALYSIS OF GROUP INTERVIEWS}

Previously outlined research (see section 3) has shown that people are motivated and encouraged to act by stimuli other than just salary; they are motivated by social approval, a sense of equity, autonomy and other non-monetary aspects of work. Job satisfaction results from the feeling that the work one is doing reflects their values and offers a sense of purpose (Depedri et al., 2010). Having in mind these and other characteristics of intrinsic and extrinsic motivations mentioned before, as well as the concepts of social entrepreneurship from the presented literature, we began analysing the qualitative data we had gathered. Having analysed the transcribed material, we isolated 38 codes grouped into eight themes, which we then divided into three categories: construction of the meaning of social entrepreneurship; cooperation; and perceived well-being.

\subsection{Constructing the Meaning of Social Entrepreneurship through Definition, Motivation, and Values}

The "meaning of social entrepreneurship" category is constructed through the themes of individual definitions (coded "personal"), motivation to work at a social enterprise, and fundamental values of social entrepreneurship (the theme "fundamentals") (Table 1). 
Table 1: "Construction of the meaning of social entrepreneurship" category

\begin{tabular}{lll}
\hline \multicolumn{2}{c}{ CONSTRUCTION OF THE MEANING OF SOCIAL ENTREPRENEURSHIP } \\
\hline $\begin{array}{l}\text { PERSONAL } \\
\text { DEFINITIONS: }\end{array}$ & MOTIVATION: & FUNDAMENTALS: \\
\hline Social inclusion & Deliberate choice & $\begin{array}{l}\text { Inclusion of the } \\
\text { marginalised }\end{array}$ \\
\hline $\begin{array}{l}\text { Social or societal } \\
\text { entrepreneurship }\end{array}$ & Circumstantial choice & Production process \\
\hline $\begin{array}{l}\text { Development of the } \\
\text { community }\end{array}$ & Self-financing & Togetherness/community \\
\hline "Textbook" definition & Work integration & Humanity \\
\hline & Public good & Opportunity in crisis \\
\hline & Helping others & Trust \\
\hline
\end{tabular}

Since there is no unique definition of social entrepreneurship and since the term is not common in the local enterprise sector (or legislation), we were interested in seeing how the actors defined social entrepreneurship, what it meant for them, and what elements of social entrepreneurship stood out as fundamental. The participants mostly defined social entrepreneurship as a type of enterprise that enables the social inclusion of marginalised groups, primarily hard-to-employ and disabled persons. This definition corresponds to the broader European context of social economy, which reduces social entrepreneurship to the integration of the marginalised and the excluded into the labour market (Work Integration Social Enterprises - WISEs) and the provision of services and social care in the community (Šimleša et al., 2015b). Furthermore, "community development" (code), that is, investing in projects of public interest is often mentioned as the defining moment of social entrepreneurship. The former part of the definition corresponds to the general definitions of social entrepreneurship, whereas the latter corresponds to concepts such as sustainable development, in the sense of emphasising development as opposed to growth. Only a fraction of the interviewees were aware of the broader definition of social entrepreneurship, which entails principles of environmental protection and reinvestment of profit, even though this definition was integrated into the local Social Entrepreneurship Development Strategy (MRMS, 2015). Since the debate on the terminology to be adopted in legislation is still ongoing in Croatia (whether the concept will be called "social" or "societal" entrepreneurship), some actors defined the concept by arguing for or against either of the terms. 
Bookkeeper/male: "To me it's... something positive. It has a social, economic, and environmental goal at once, and it is actually a type of entrepreneurship that will give a chance to those that no one in conventional entrepreneurship wants to employ."

In the interviews, we asked questions about the motivation for working at a social enterprise. We also wanted to know whether the individuals had made clear decisions to work in the social enterprise sector or whether this was a "circumstantial choice", as some participants said - that is, whether they would have accepted any job to make a living. The analysis showed that motivation was closely interconnected with the definition of social entrepreneurship: the definition aligned with the participant's motivation to do specific work (such as "helping others" or environmental protection) and with what they do at the social enterprise (for instance, finding jobs for the hard-to-employ, or upcycling textile). It can also be said that the interaction between these processes goes both ways: the motivation is supported by the definition and the definition justifies the motivation.

Project manager / female: "I've always had the need to help others, and this organisation is conceived this way. Any one of us could have had a private business and be successful. But the thing is, it's our own choice to be part of the success of the whole community."

These findings are also somewhat consistent with the research conducted in Italy and Great Britain, where the importance of the intrinsic motivation for working in this sector was manifested, inter alia, in the importance of social impact for the individual/participant and the perceived purpose of work (Chandler, 2016; Depedri et al., 2010). However, most of the interviewees said their job choice was circumstantial, whereas the rest deliberately sought employment in the sector - these were mostly individuals in management positions.

Motivation is also closely linked to what the actors see as the most important (fundamental) aspect of social entrepreneurship. When we asked the participants to single out the most important aspect or the fundamental value of social entrepreneurship, they emphasised the values or aspects that corresponded to their answers about definition and motivation. If a cooperative works with marginalised groups, this reflects on the way the interviewees (cooperative employees) define social entrepreneurship and the values they highlight as the determining factors of social entrepreneurship, such as humanity or social inclusion of marginalised groups. The topic of fundamentals also encompasses some of the codes, such as "trust" or "togetherness", which correspond to the mentioned research to a certain 
extent in this case as well (particularly to the findings of Sabatini et al. (2012) and Chandler (2016)). Some participants only singled out values that referred to the enterprise, whereas others highlighted values that referred to the broader social impact of the enterprise.

Food factory worker / female: "For me, the most important aspect is solving real problems in the community... catering to people's needs. What is also important is the production process, in which not only the final product is important, or profit, but people are important, too."

Hortitherapy coach / female: "What I deem most important in the company are cooperation and togetherness... We decide on everything in a democratic way, and cooperation and trust are a priority."

The above quotations illustrate how the social-contextual factor as an aspect of the interpersonal climate in the workplace promotes trust and job satisfaction (Baard et al., 2004).

\subsection{Perceived Well-Being}

As the previously outlined research has shown, motivation is closely connected to job satisfaction (Baard et al., 2004). This is also the case in our research, which is shown through the themes of "working conditions" and "personal fulfilment" that constitute the second category we singled out in our analysis: "perceived well-being". These two themes also somewhat match the self-regarding and other-regarding intrinsic motivations (Becchetti et al., 2013), as well as some of the elements of intrinsic need satisfaction like personal endorsement, autonomy, competence, and relatedness, which Ryan and Deci (2000) consider important for improving self-motivation, satisfaction, and performance at the workplace.

We asked the interviewees to describe their working conditions, how working at a social enterprise impacted their life, and to describe the differences between working at a conventional business and a social enterprise (since almost all participants had previous work experience). They mostly answered the questions positively: most of them reported an increase in the quality of life, particularly in terms of "usefulness" for society. The latter may also be interpreted as the successful achievement of one of the social entrepreneurship goals, which is the social integration of those workers who can be classified as part of marginalised groups. 
Table 2: "Perceived well-being" category

\begin{tabular}{ll}
\hline & PERCEIVED WELL-BEING \\
\hline PERSONAL FULFILMENT: & WORKING CONDITIONS: \\
\hline Improved quality of life & Democratic decision-making \\
\hline Impaired quality of life & Equal opportunities \\
\hline Work satisfaction & Work satisfaction \\
\hline Integration & Family atmosphere \\
\hline Internalisation of values through SE & Personal relations \\
\hline Circumstantial choice / deliberate choice* & Employee interdependence \\
\hline
\end{tabular}

*The "circumstantial choice" and "deliberate choice" codes appear in two categories.

Furthermore, some interviewees emphasised that working at a social enterprise helped them internalise new values and adopt new attitudes related to environmental protection and helping those in need. This is seen as an example of personal endorsement, especially for those workers who started their "career" prompted mostly by extrinsic motivation (monetary compensation and security). Through personal endorsement, interviewees report a positive impact on psychological well-being through the feeling of usefulness.

Physical therapist / female: "Well, any job that pays my bills every month is improving my quality of life [laughter]. No, for real, I was looking for a job for a whole year, and every employer, when he sees my diagnosis, loses interest in hiring me. Working here has really made me happy, my life has improved drastically, it's not just about the salary, it's about feeling useful."

The interviewees were also satisfied with their working conditions and often mentioned that interpersonal relations were more important than a high salary. The ability to advance at work, the right to partake in decision-making, equality, and a "family atmosphere" were the most commonly mentioned advantages of working at a social enterprise, which further amplify motivation and job satisfaction, and are practically in line with the goals of social entrepreneurship.

Seamstress 1 / female: "Yeah, I worked at a company that... runs for profit. But here, there is no such pressure, it's much more relaxed, and the conditions are much more humane." 
Seamstress 2 / female: "I think we are like one big family. I worked for 27 years at another company... and always had to keep my head down, be quiet, and obey orders. But now, we decide everything together, and I'm reborn!"

Employee manager / male: "We had some tough times. For two years, we worked for a minimum wage. Someone might find it hard to understand, but I would rather work for a minimum wage and have good interpersonal relationships at the workplace than to earn twice as much and have to endure stress."

Only a small portion of the participants felt that there had been negative effects on the quality of life since they spent more time at work (this particularly refers to the participants in foreman positions), but they also pointed out that it wasn't "a problem".

We again see that the results of the research correspond to the conclusions of Depedri et al. (2010), and Macaulay et al. (2017) regarding the importance of the perceived 'usefulness', autonomy and social impact for the perceived job satisfaction and overall well-being. The correspondence also refers to the way that an autonomy-supportive context ("humane" working conditions, "interpersonal relationships", not "obeying orders") enhances self-motivation and personal endorsement (Baard et al., 2004) that bring motivation closer to being intrinsic but also enhances overall job satisfaction, participants' overall impression of an improved quality of life related to positive surroundings, cooperation, and equality. There is also correspondence to previous findings (Chandler, 2016) regarding the negative aspects of the quality of life such as poor work-life balance.

\subsection{Cooperation}

Apart from being directly linked to employees' motivation or shared values, cooperation with the community, as well as within and among enterprises, is a vital segment of social entrepreneurship. It proved to be a very important topic among our participants as well, particularly in the context of relations with the local community and users. The "cooperation" category encompasses 12 codes grouped into three themes. 
Table 3: $\quad$ The "cooperation" category

\begin{tabular}{lll}
\hline \multicolumn{3}{c}{ COOPERATION } \\
\hline $\begin{array}{lll}\text { COOPERATION IN A } \\
\text { BROADER CONTEXT }\end{array}$ & $\begin{array}{l}\text { RELATION TO THE } \\
\text { COMMUNITY }\end{array}$ & COMPETITION \\
\hline Lack of cooperation & $\begin{array}{l}\text { Good communication with } \\
\text { users }\end{array}$ & $\begin{array}{l}\text { No competition among SE } \\
\text { actors }\end{array}$ \\
\hline Need for networking & Recognition in the community & Competition for projects \\
\hline Good cooperation & $\begin{array}{l}\text { Ineffective cooperation with } \\
\text { the local government }\end{array}$ & $\begin{array}{l}\text { Competition with conventional } \\
\text { entrepreneurship }\end{array}$ \\
\hline
\end{tabular}

Third-sector support

Market cooperation

Free market rules

When the interviewees were asked to rate cooperation in terms of social entrepreneurship, we received conflicting answers. Some of the interviewees were satisfied with the cooperation within the social enterprise sector; a part of them expressed their dissatisfaction with cooperation and emphasised the need to "network" to increase market success. Some participants pointed to cooperation with conventional enterprises as desirable in terms of growth and development of social entrepreneurship. They also saw a learning potential since social entrepreneurs have to function within the broader free-market context. In this respect, the participants also saw obstacles to the development and survival of a social enterprise since some of them, due to the overall production model, cannot compete with conventional businesses in terms of price.

Graphic designer / male: "I think that with more cooperation we could get much better results... by networking and partnering up, we could create a common market for our products. There are already several conventional businesses that work with us and that circle is growing every year."

In-home elderly care worker / female: "It's difficult to initiate cooperation because people are not ready. And I believe this is a general Croatian trait. That is why we see project partnerships only on paper, but not as true participatory initiatives."

On the other hand, the majority of the interviewees emphasised good cooperation with users, confirmed by good communication with their users and the fact that they kept coming back to use their goods and services ("regular customers"), which 
contributed to positive workplace experience, and the enhancement of motivation. As one interviewee said, "The customers are very considerate, they understand the matter. Those are our regulars, so they know our families and we know theirs"(physical therapist/male).

They also considered the position of certain actors (cooperatives) in the local community as positive, whereas only a few interviewees spoke negatively about cooperation with the local government, particularly in terms of the absence of concrete support measures.

The issue of competition arises with cooperation. The interviewees spoke of good relations and the absence of competition within the social enterprise sector, attributing it to the fact that social entrepreneurship in Croatia is still underdeveloped, which leaves plenty of room for a variety of market choices. The participants from one cooperative were the only ones to point out that there was competition in the context of applying for public tenders for financing social enterprise projects. It is also valid to assume that external factors of social enterprises' ecosystems and various public policies influence the conflicting aspect of cooperation and competition mentioned by the interviewees. Specifically, we can refer to the external factors listed in the report Social Enterprises and their Eco-System (EC, 2016: 19): 1) the political acknowledgement and legal forms that have been recognised at the national level; 2) access to market; 3) public support; 4) access to finance; 5) networks and mutual support mechanisms; 6 ) research, education and skills development. These factors are underdeveloped in Croatia, which could be connected to the attitudes of workers in social enterprises towards cooperation among the relevant actors, public/institutional awareness, and institutional obstacles to the sectors' development. ${ }^{6}$

\section{DISCUSSION}

There are several points of correspondence between our findings and previous research. First, we confirmed that the intrinsic motivation for working in this sector is manifested in the importance of social impact and the perceived purpose of work. This also applies to the conclusions regarding the importance of the connection between perceived "usefulness", autonomy and social impact for perceived job satisfaction and overall well-being. Second, our findings confirm the importance of trust and interpersonal climate at the workplace for both motivation and job satisfaction. More specifically, this refers to the way that an autonomy-supportive context en-

6 The socio-political and legislative frameworks are important for understanding the development of social entrepreneurship in Croatia. However, the subject exceeds the scope and focus of this paper. Valuable insight on this topic can be found in Vidović (2019). 
hances self-motivation and personal endorsement that further reinforce overall job satisfaction and participants' impression of improved quality of life. Third, there is also correspondence to previous findings regarding the negative aspects of quality of life, such as poor work-life balance.

We further extended these findings with the conclusion that motivation, values, and definition of social entrepreneurship are closely interconnected for social economy workers. Furthermore, those three aspects also lead to, and the same time are supported by perceived well-being through working conditions and personal fulfilment. In other words, values and motivation are supported and enhanced by working conditions and personal fulfilment on the job. Correspondingly, shared values and motivation improve the social-contextual aspect of a job and create an interpersonal climate. The aspect of cooperation is not as directly connected to motivation, values, and well-being but has shown to be important to the interviewees and it can also have a positive impact on these categories through positive relations with the community/users. There are certain differences in opinion among participants due to experiences in different enterprises, and they contribute to the complexity of the results in terms of the research question.

Furthermore, our analysis showed that the ability to advance at work, right to partake in decision-making, equality, and a "family atmosphere" are manifestations of the theoretical conceptualisation of social entrepreneurship regarding participatory/horizontal management.

Finally, we built on and extended the previous research findings that altruistic components impact the motivation for working in the sector (Borzaga et al., 2014). We conclude that through the internalisation of social entrepreneurship values, the opposite is also true. Working at a social enterprise creates and enhances altruistic components of motivation.

All of the above allows social enterprises to fulfill the mission of the social enterprise sector, including social impact, a high degree of autonomy and participatory nature. The mission of social entrepreneurship is fulfilled despite the underdevelopment of the sector in Croatia and the fact that no regulatory framework has been established. 


\section{CONCLUSION}

Social economy actors and social enterprises are becoming increasingly accepted as solutions to growing social, economic, resource, and environmental issues in the $21^{\text {st }}$ century, and they are particularly lauded as a tool for achieving many of the 17 Sustainable Development Goals until 2030 (Trosi, Sisto and Castagnola, 2017). The research presented here pointed to the existence of self-motivation in our social enterprises and a high level of job satisfaction and participation in the organisations. This points to the conclusion that social enterprises in Croatia, in their nascent stage, fulfil their mission regarding social impact, high level of autonomy and participatory management in the workplace. The described work experiences in social enterprises from the employee perspective have afforded us a broader understanding of the impact of social entrepreneurship, both in the context of the initial development of the sector (such as the one in Croatia) and in the context of an economic crisis.

Considering these results in the framework of the conducted qualitative analysis, we can speak about the theoretical generalisation of the results (Eisnhart, 2009). In that regard, we do not achieve the generalisation of the results based on the statistical representability of the sample as in quantitative research. Rather, we speak of the generalisation of theoretical concepts that can help further develop the theory and theoretical concepts of social entrepreneurship. According to Gobo (2007), developing precise sample variability (as part of idiographic sampling) is one of the crucial steps for attaining generalisation in qualitative studies. Having in mind the variability included in our research sampling, we can attempt to claim the theoretical generalisation of our results. In the case of research presented here, generalisation will, therefore, apply to the relationship between workers' construction of the meaning of social entrepreneurship, their job experience and perceived well-being in the sector of social entrepreneurship, as well as the relationship between the aforementioned aspects and participatory management. In that regard, this research and its results are a first step towards the further development of the explanatory framework in the research of participatory management impact and towards the further strengthening of generalisation by elaborating sample variability. There are, however, specific limitations to this research: we cannot claim with certainty that the perceived increase in life quality, intrinsic motivation, and values are exclusively a result of working at a social enterprise. Other factors may have contributed to the researched phenomena such as the size of the organisation (since all the organisations/cooperatives included in the research were small organisations) because the work climate in smaller organisations sometimes tends to be more personal and relations between workers closer. Second, the study's out- 
comes may have been influenced by the group setting of the interviews, where the interviewees may have influenced and inspired each other's answers. However, all interviewees were workers (mostly in the same job positions within the group) and never cooperative managers and/or founders who might have influenced the theme and tone of the conversations. Third, some participants, especially those who chose to work at a social enterprise, may have had an a priori positive opinion of working at a social enterprise, which could have influenced the resulting outcome. However, a part of the validity of our findings stems from the comparison with the participants who "happened" to enter the social enterprise sector; they considered working in the sector to be positive compared to previous experiences with differently organised jobs and institutions.

The academic contribution of this paper consists of expanding the explanatory framework of the way motivations, values and personal definitions of social entrepreneurship interact with job satisfaction, perceived well-being, and participatory management. It also consists of a revelation of the direction of the mentioned interactions: not only are altruistic and intrinsic components important for the motivation to work at a social enterprise but working at a social enterprise will impact and enhance the altruistic and intrinsic components of motivation that were not present before. This opens up new areas of research in order to encompass all the relevant aspects that the participants of this research singled out, for instance, the development of precise measurements of the impact of democratic management in the workplace on work motivation, work performance and, consecutively, job satisfaction. Research on the level of democratic government in the workplace, job experience and inclusion of all key stakeholders in the (co)decision-making process is necessary not only in the context of social entrepreneurship but also in the context of developing more sustainable and fairer economy models.

\section{FUNDING}

This paper was supported by the Croatian Science Foundation, Installation Research Projects Grant, 5332 iPRESENT - Installation Project for REsearch about Social ENTrepreneurship. 


\section{REFERENCES}

Acocella I (2011). The Focus Groups in Social Research: Advantages and Disadvantages, Quality and Quantity, 46(4): 1126 - 1137. https://doi.org/10.1007/s11135-011-9600-4

Attride-Stirling J (2001). Thematic Networks: An Analytical Tool for Qualitative Research, Qualitative Research, 1 (3): 385-405.

Baard P, Deci E and Ryan R (2004). Intrinsic Need Satisfaction: A Motivational Basis of Performance and Well-Being in Two Work Settings, Journal of Applied Social Psychology, 34 (10): 2046-2068. https://doi.org/10.1111/j.1559-1816.2004.tb02690.x

Baturina D (2018). Za nestabilnost spremni? Utjecaj dionika i procesa trećeg sektora na njegove ljudske resurse, Sociologija i prostor, 56(2(211)): 37-159. https://doi.org/10.5673/ sip.56.2.3

Becchetti L, Castriota S and Tortia, E (2013). Productivity, Wages and Intrinsic Motivations, Small Business Economics, 41 (2): 379-399. https://doi.org/10.1007/s11187-012-9431-2

Bell, E and Willmott, H (2014) Editor's Introduction: Qualitative Research - Themes and Prospects. In Bell, E and Willmott, $\mathrm{H}$ (eds.) Major Works in Qualitative Research in Business and Management. London: Sage, xix

Bežovan G, Matančević J and Baturina D (2016). The Croatian Third Sector in 2015. Barriers and Way Foward. http://thirdsectorimpact.eu/site/assets/uploads/documentations/tsipolicy-brief-no-6-croatian-third-sector-2015-barriers-way-forward/TSI-Policy-Brief-6 Croatia-.pdf (12 February 2020)

Borzaga C and Galera G (2014). New Trends in the Nonprofit Sector in Europe: The Emergence of Social Enterprises. In: Costa, E, Parker, L and Andreaus, M (eds). Accountability and Social Accounting for Social and Non-Profit Organizations (Advances in Public Interest Accounting, Volume 17). Emerald Group Publishing Limited, 89-110. https://doi.org/10.1108/S1041-706020140000017002

Borzaga C, Bodini R, Carini C, Depedri S, Galera G and Salvatori G (2014). Europe in Transition: The Role of Social Cooperatives and Social Enterprises. Euricse Working Papers, 69|14. https://www.euricse.eu/wp-content/uploads/2015/03/1405514708_ n2553.pdf (24 April 2019)

Bouchard J (2010). The Worth of the Social Economy. An International Perspective. Brussels: Peter Lang Publishing.

Brown G and Edmunds S (2011). Doing Pedagogical Research in Engineering. Leicestershire: Engineering Centre for Excellence in Teaching and Learning.

Comolli L, Varga E and Varga, P (2007) Pokreni se - iskustva održivog socijalnog poduzetništva u Hrvatskoj, Zagreb: NESST

Chandler J (2016). A Study to Explore the Impact of Working in a Social Enterprise on Employee Health and Wellbeing in Greater Manchester, PhD thesis, University of Salford. https://usir.salford.ac.uk/id/eprint/40753/1/THESIS\%20FINAL.pdf (06 April 2019.)

Charmaz K (2000). Grounded Theory - Objectivist and Constructivist Methods. In: Denzin $\mathrm{N}$ and Lincoln $\mathrm{Y}$ (eds). Handbook of Qualitative Research, 2nd edition. London: Sage publications, 509-532.

Defourny J and Nyssens M (2012). The EMES Approach of Social Enterprise in a Comparative Perspective WP No. 12/03. www.emes.net. (23 April 2019) 
Depedri S, Tortia E and Carpita M (2010). Incentives' Job Satisfaction and Performance: Empirical Evidence in Italian Social Enterprises. Euricse Working Papers, N.012 | 10. http://www.euricse.eu/wpcontent/uploads/2015/03/WP_012_Depedri_Tortia_Carpita_ ENG_sd.pdf (23 April 2019)

European Commission (2013) Social Economy and Social Entrepreneurship, Social Europe Guide Vol. 4, https://sofisam.se/download/18.3453fc5214836a9a47 2a0430/1472023483855/EU+kommissionen,+Social+Economy+and+Social+Entreprenreurship.pdf (22 April 2019)

European Commission (2016). Social Enterprises and their Eco-systems: Developments in Europe. http://ec.europa.eu/social/main.jsp?catld=738\&langld=en\&publd=7934\&furtherPubs=yes (20 April 2019)

Eisenhart M (2009). Generalization from Qualitative Inquiry. In: Ercikan K and Roth W (eds). Generalizing from Educational Research: Beyond Qualitative and Quantitative Polarization. New York: Routledge, 51-66.

European Parliament (2009): Report on Social Economy, 2008/2250(INI), http://www. socialeconomy.eu.org/IMG/pdf/http__www-europarl-europaeu_sides_getDoc.pdf. (19 December 2018)

Fitzhugh $\mathrm{H}$ and Stevenson N (2015). Inside Social Enterprise - Looking to the Future. Bristol: Policy Press.

Gobo G (2007). Re-conceptualising Generalization: Old Issues in a New Frame. In Alasutari P, Bickman L and Brannen J (eds). Sage Handbook of Social Research Methods. Los Angeles: Sage, 193-213. https://doi.org/10.4135/9781446212165.n12

Jackson T (2009). Prosperity without Growth - The Transition to a Sustainable Economy. http://www.sd-commission.org.uk/data/files/publications/prosperity_without_growth_ report.pdf (10 April 2019)

Macaulay B, Roy MJ, Donaldson C, Teasdale S and Kay A (2017). Conceptualizing the Health And Well-Being Impacts of Social Enterprise: A UK-Based Study, Health Promot Int., 33(5): 748-759. https://doi.org/10.1093/heapro/dax009

Millstone C (2013). The Potential of Social and Solidarity Economy (SSE) Organizations to Complement or Replace Publicly Traded Companies in the Provision of Goods and Services. http://www.unrisd.org/80 256B42004CCC77/\% 28httpInfoFiles\%29/8EDE666368A12E10C1257B720035E9D0/\$file/Millstone\%20 draft\%20paper.pdf. (23 April 2019)

Monzón Campos J and Chaves Avila R (2010). Socijalna ekonomija u Europskoj uniji, Revija za socijalnu politiku, 17 (1): 113-138. https://doi.org/10.3935/rsp.v17i1.936

Monzón Campos $\mathrm{J}$ and Chaves Avila R (2016). Recent Evolutions of the Social Economy in the European Union. Brussels: CIRIEC.

MRMS (2015). Strategija razvoja društvenog poduzetništva u Republici Hrvatskoj za razdoblje od 2015. do 2020. godine. http://www.esf.hr/wordpress/wp-content/ uploads/2015/02/Strategija-razvoja-dru\%C5\%A1tvenog-poduzetni\%C5\%A1tva-u-RHza-razdoblje-2015-2020.pdf (15 March 2015)

OECD (2013) Policy Brief on Social Entrepreneurship - Entrepreneurial Activities in Europe. http://www.oecd.org/cfe/leed/Social\%20entrepreneurship\%20policy\%20brief\%20EN_ FINAL.pdf. (02 March 2019)

Perić J and Alpeza M (2011). Policy pretpostavke za razvoj socijalnog poduzetništva: slučaj Hrvatska. Tuzla: Zbornik međunarodnog znanstvenog skupa, Ekonomski fakultet. 
Pérotin V (2015). What Do We Really Know About Workers' Cooperatives?. In: Webster T, Shaw L and Vorberg-Rugh R (eds). Cooperation: A Business Model for the 21st Century. Manchester: Manchester University Press, $1-23$

Rosandić A and Varga P (2012). An Assessment of Self-Financing and Social Enterprise Among Civil Society Organizations in Croatia - Developments Since 2006. Zagreb: NESST.

Ryan R and Deci E (2000). Intrinsic and Extrinsic Motivations: Classic Definitions and New Directions, Contemporary Educational Psychology, 25 (1): 54-67. https://doi. org/10.1006/ceps.1999.1020

Sabatini F, Modena F and Tortia E (2012). Do Cooperative Enterprises Create Social Trust? EURICSE Working Paper No. 043|12. https://doi.org/10.1007/s11187-013-9494-8

Smithson J (2007). Focus groups. In: Alasutari P, Bickman L and Brannen J (eds). Sage Handbook of Social Research Methods. Los Angeles: Sage, 356-371.

Stiglitz J, Sen A and Fitoussi J (2009). Report by the Commission on the Measurement of Economic Performance and Social Progress. https://ec.europa.eu/eurostat/ documents/118025/118123/Fitoussi+Commission+report_(23 April 2019)

Stubbs P and Vidović D (2017). Social Enterprise in Transition: A Case Study of ACT Group, Društvena istraživanja, 26 (2): 143-163. https://doi.org/10.5559/di.26.2.01

Šimleša D, Puđak J, Majetić F and Bušljeta Tonković A (2015a). Mapiranje novih obzora izvještaj o stanju društvenog poduzetništva u Hrvatskoj 2015. Zagreb: Institut društvenih znanosti Ivo Pilar. https://www.kulturpunkt.hr/sites/default/files/izvjestaj-mapiranjenovih-obzora.pdf (13 April 2019)

Šimleša D, Puđak J, Majetić F and Bušljeta Tonković A (2015b). Preko granica - društvena ekonomija u Europi. Zagreb: Institut društvenih znanosti Ivo Pilar. https://www.pilar.hr/ wp-content/uploads/2018/01/preko_granica_novo.pdf (12 November 2015)

Šimleša D, Puđak J and Bušljeta Tonković A (2019) Social Entrepreneurship in Croatia: Its Future, the Actors Database, and the Strategy. In Šimleša, D (ed.) Social Entrepreneurship in South East Europe. Zagreb, Institute of Social Sciences Ivo Pilar, 27-44.

Troisi R, Sisto M and Castagnola A (eds.) (2017) Final Analysis of the SSEDAS Research Transformative Economy: Challenges and Limits of the Social and Solidarity Economy (SSE) in 55 Territories in Europe and in the World, https://base.socioeco.org/docs/susy_ research_240517_1_.pdf (13 March 2018)

Utting P (2015). Social and Solidarity Economy - Beyond the Fringe. London: Zed Books.

Vidović D (2019). Social Cooperatives in Croatia: The Emergence and Development of a New Type of Cooperative. In: Šimleša D (ed). Social Entrepreneurship in South East Europe. Zagreb: Institute of Social Science Ivo Pilar, $45-62$. 


\section{Je li društveno poduzetništvo bolje za radnike? Utjecaj radnog iskustva u hrvatskim društvenim zadrugama na percipiranu dobrobit radnika}

Jelena PUĐAK (D) orcid.org/0000-0002-0549-5802

Institut društvenih znanosti Ivo Pilar, Hrvatska

jelena.pudjak@pilar.hr

Dražen ŠIMLEŠA

Institut društvenih znanosti Ivo Pilar, Hrvatska

drazen.simlesa@pilar.hr

\section{SAŽETAK}

Osnovna je namjera ovoga rada istražiti motivacije, vrijednosti i zadovoljstvo na radnome mjestu radnika zaposlenih u sektoru društvenog poduzetništva. Kvalitativnim istraživanjem obuhvatili smo deset socijalnih zadruga kako bismo interpretirali iskustva rada u društvenom poduzetništvu iz perspektive samih radnika. Iz rezultata istraživanja može se zaključiti kako sugovornici/radnici u društvenim poduzećima daju prednost intrinzičnoj motivaciji i intrinzičnim vrijednostima vezanim uz radno mjesto, pozitivno opisuju uvjete rada u društvenom poduzetništvu te dijele percepciju porasta kvalitete života otkad rade u društvenom poduzeću. Veze koje smo opisali u istraživanju između motivacija, radnog iskustva i participatornog upravljanja omogućuju proširenje postojećih zaključaka istraživanja motivacija i zadovojstva na radu u sektoru društvene ekonomije.

Ključne riječi: društveno poduzetništvo, intrinzična motivacija, vrijednosti, zadovoljstvo na radnome mjestu 